\title{
Professor Pedro Clóvis Junqueira
}

Nelson Hamerschlak

Instituto Israelita de Ensino e Pesquisa Albert Einstein - IIEPAE São Paulo, (SP) Brazil
Submitted: $1 / 24 / 2011$

Accepted: 1/25/2011

Correspondence: Nelson Hamerschlak Instituto de Ensino e Pesquisa Albert Einstein Av Albert Einstein 627 sala 1203 Morumbi

05651-901 - São Paulo (SP), Brazil

Phone $55113747-3203$

hamer@einstein.br

www.rbhh.org or www.scielo.br/rbhh

DOI: $10.5581 / 1516-8484.20110022$

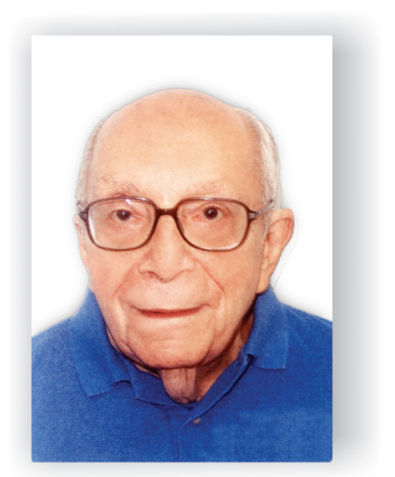

Clovis Pedro Junqueira, considered a living legend in transfusion medicine in Brazil died on October 2, 2011, at the age of 94 years. Until about 1 or 2 years ago, Professor Junqueira was still active, receiving honors and being interviewed and consulted about the future of hemotherapy in Brazil. He was seen in the library that bears his name at the headquarters of the Brazilian Society of Hematology and Hemotherapy (SBHH), studying, consulting international journals and the internet in order to keep himself up to date. It could not have been different: all his lifetime, Professor Junqueira devoted himself to transfusion medicine in Brazil; he scientifically and personally influenced several generations. The library of the $\mathrm{SBHH}$ should now receive in its collection, the books of this illustrious visitor, in fact many rare books in perfect condition were already donated while he was alive. Hematology will always have the works that he edited: 'the Essentials of Blood Transfusion', 'Peri-Natal Hemolytic Disease' and last year with Jacob Rosenblit and myself, 'Clinical Transfusion Medicine', a book that summarizes his philosophy of changing the transfusion medicine specialist inside the blood bank from someone who follows prescriptions to being active with colleagues of other specialties, and especially with his patients.

Born in Sao Luiz, Maranhão on June 1, 1916, he was still a child he moved with his family to Rio de Janeiro, the then capital of the country. His Portuguese father was hoping to find opportunities in trade, but he became attracted to medicine and in 1939 he graduated at the National Medicine School of Brazil in Rio de Janeiro. He was a disciple of Walter Oswaldo Cruz and his training included stints in England, Germany, Holland, France, Argentina and the United States, as he passed in first place in the Postgraduate Course in Hematology at the Oswaldo Cruz Institute.

In 1945, he began to devote himself to transfusion medicine and founded a service in Rio de Janeiro. Later, he joined Prof. Dr. Hildebrando Monteiro Marinho, merging hematology and transfusion medicine into one single unit.

With Walter Oswaldo Cruz he gave the first course of specialization in hematology in Manguinhos in 1949. In the same year, he was one of the organizers of the First Paulista Congress of Hematology. The event started on June 8, lasted four days and produced 30 recommendations, including the establishment of the First Brazilian Congress.

Along with Carlos da Silva Lacaz, Oswaldo Mellone and Michel Abu Jamra, he founded the Sociedade Brasileira de Hematologia e Hemoterapia (Brazilian Society of Hematology and Hematology), scheduling the First Brazilian Hematology Congress for the 21 to 26 of May 1950, at which time the society became official. Besides Pedro Junqueira Clovis, the organizing committee included Walter Oswaldo Cruz, Heraldo Maciel, Artur Cavalcante, João Maia Mendonça, Frederico Ottensooser, Oswaldo Mellone, Michel Abu Jamra, Ruy Faria, Carlos da Silva Lacaz, Menandro Novaes, Côrtes Villela and Carlos Estevão Frimm.

In 1951, Professor Junqueira presented papers on blood groups in Brazilian Indians in two international conferences in Portugal and Italy. In the same year, he participated in 
the creation of the Human Genetics Commission of the Brazilian Society of Genetics. In 1954 he led the Brazilian delegation to the Fifth Congress of the International Society of Blood Transfusion held at the Sorbonne in Paris. That same year, he worked on projects together with Jean Dausset and AE Mourant.

Professor Junqueira was elected president of the Brazilian Society of Hematology and Hemotherapy for two consecutive terms; he worked very hard for the recognition of the specialty and was responsible for the acquisition of the Society's own headquarters. He was awarded honorary professor and honorary president of the Brazilian Society of Hematology and Hemotherapy.

He also participated in several scientific societies and other entities, as full member of the Brazilian College of Surgeons, president of the Brazilian Society of Clinical Pathology, a member of the Advisory Board of the International Society of Blood Transfusion, member of the Human Genetics Commission of the Brazilian Society of Genetics, director of the Physician Continuous Education Center of the Department of Health, president of the Latin American Society of Hematology and a member of the Technical Division of Hematology of the National Health Council.

Post-graduation professor of Hematology of PUC-RJ and former Regent Professor of Genetics, he gave six postgraduate courses, 20 courses on hematology, more than 170 classes, with more than 42 courses in his curriculum. Additionally, he published more than 40 scientific papers in prominent journals. It is important to note that Professor Junqueira is one of the few Brazilians with publications in the journal Nature in which he published three papers. He wrote and translated books, wrote chapters in books and several monographs. He participated in 70 national and 27 international conferences, including 24 meetings of the American Association of Blood Banks. In these conferences, he presented a hundred papers, participated in 85 round tables and gave 35 lectures.

Throughout his career, he also received several other awards, including the Laboratory Prize of the Academic
Society of Medicine and Surgery of Rio de Janeiro in 1939, the "Merit. Prof. Clementino Fraga" medal awarded by the Governor of Guanabara in 1974, Diploma of Great homage given by the Brazilian Society of Clinical Pathology, the title of Professor Emeritus of the Medical School of Teresópolis in 1987 and the Alfred Juazykowski Award by the National Academy of Medicine in 1998.

In 1992, with a wonderful monograph on auto transfusion, he became a member of the National Academy of Medicine.

In 2000, he was chairman of the XXIV Brazilian Congress of Hematology, celebrating the fiftieth anniversary of the Brazilian Society of Hematology and Hemotherapy. The competence and care, characteristics of Professor Junqueira were apparent in every detail of the scientific and social programs.

His contribution to Brazilian transfusion medicine was so important that, at this time, he was honored by our colleague Marcos Pimentel Alfredo with a book about his life called: The Trajectory of a Master.

In 2008, during a hospital stay, he became enthusiastic when he heard about the merger between the SBHH and the Brazilian College of Hematology to form the Brazilian Association of Hematology (ABHH). Even when Professor Junqueira was recovering from health problems, he did not forget and even continued to influence decisions in his field.

More important than everything else, more important than any title or award, he was human; Clovis Pedro Junqueira, or Pierre Clochard as he liked to be called. Father, grandfather, loyal friend and wonderful husband, an enviable man of culture, fond of all the causes he embraced, he was an example and encouragement to us all. A fanatical supporter of Flamengo Football Club, admirer of a good whiskey and fine wine, Mr. Junqueira was married to Norma, the secret to his everlasting youthfulness.

Professor Junqueira will always be remembered for his professional competence, wisdom, intellect, simplicity, humility and his "joie de vivre." 